\author{
Anne-Marie Barrault-Méthy \\ Univ. Bordeaux, EA 3810 FoReLL, Univ. de Poitiers, France
}

\title{
OBSCURITY IN THE MICROPOLITICS OF ENGLISH FOR LEGAL PURPOSES: TOWARDS AN ANTHROPOLOGICAL FRAMEWORK
}

Summary. Research in English for Legal Purposes (ELP) has expanded in the past 30 years, in parallel with the increasing attractiveness of transnational legal education. The present paper aims at observing how ELP research has dealt with the issue of globalisation of law studies, considering that legal taxonomies remain largely national. The analysis expands on the application of Anthropological Structures of the Imaginary (ASI) theory (Durand 1969) to a language policy context to describe the positioning of ELP researchers and law experts in relation to each other. Focusing on the notion of posture, an the analysis of images in a corpus of 68 ELP research papers suggests that the theme of obscurity lies at the heart of ELP research discourse. Power-related images fall into the four broad categories of animality, depression, the fall and the labyrinth. The contribution of ASI theory to the study of the micropolitics of ELP thus appears to be two-fold. ASI theory sheds light on the metadiscourse on power that runs through ELP research and that helps understand agents' positioning. ASI theory applied to ELP research eventually sheds light on the aporia (Glanert, 2005) Legal English researchers and law experts are faced with in an English as a Lingua Franca (ELF) context.

Keywords: Language management theory, Languages for Specific Purposes, English for Legal Purposes, Anthropological Structures of the Imaginary theory, positioning theory, micropolitical level.

Law is one of the most popular subjects at university and one which has attracted the most international students to English-speaking countries, according to the OECD. In France in 2011, law was the subject which attracted the most students, chosen by 13.3 percent of them, ahead of Human and Social Sciences and Medical Science. The phenomenon is all the more interesting, and paradoxical, in the context of globalisation given that the language of law is country-specific and that universities remain, by and large, a national enterprise (Sharma 2010). How is the delivery of English for Law organised internationally, then, if it is determined by an understanding of "the law", the term being taken broadly, based on taxonomies rooted in national history? What is the English taught in classes of English for Legal Purposes (henceforth abbreviated ELP) as a Lingua Franca (ELF) context? What is the relationship between ELF and English for Legal Purposes? 
These questions are of particular interest for language policy and planning research considering the many stakeholders who might benefit from them being answered. There is currently surprisingly little visibility coming from the different models of ELP provisions worldwide. An understanding of such models could inform curriculum planning in Law, Language and Teacher Training. Language teachers at Law faculties often have little training, if any, on the subject-specific challenges set by ELP. Teachers are mostly unaware of the many words which, used in a non-specific context, may take on a completely different meaning in a legal context, both in the L1 and in the L2 (Bruce, 2002). Law typically poses "unpredicted problems in subject knowledge during class", which Wu \& Badger (2009) have conceptualised as In-Class Subject Knowledge Dilemmas (ISKDs).

The present paper is a part of a two-fold synthesis of ELP research on the micropolitics of ELP from an anthropological perspective. ELP has been a vibrant field of research in the past 30 years or so. To give one example drawn from the French national context, English for Specific Purposes is the fourth branch of Anglophone studies, alongside civilisation, linguistics and literature. Among the national academic societies that deal with ESP, the Groupe d'Etudes et de Recherches sur I'Anglais de Spécialité (GERAS) counts a law Special Interest Group (SIG), which has been in existence since 1998, and which is the SIG with the most members. ELP can therefore be considered as one major language policy sub-theme of English for Specific Purposes, a language policy theme in itself alongside such other themes as the CEFRL, mobility, plurilingualism, translation and social inclusion. The present study will focus on studying the distinctive, relatively under-researched voice to date (Canagarajah, 1996, Norton \& Early, 2011, Dressen-Hammouda, 2014) voice of the ELP researcher as a language policy agent, among such other agents as law-makers, judges, Law professors and law experts in general, as well as students.

The main theoretical framework of such analysis is Durand's Anthropological Structures of the Imaginary (ASI) theory (1969). The assumption is that in the university context, ELP research is a sensitive, politically-laden issue and that forms a coherent body of language policy literature in which the domination of Law as a subject is symbolically expressed 
through recurring motives. We will unfold the discourse of research organised around the theme of obscurity which determines the posture of the ELP researcher and, conversely, of the law expert. The implications of the results for language policy and planning (LPP) research and practice will be dealt with in the conclusion.

\section{Background}

\section{Language management theory}

The present study builds on Spolsky's language management theory (2009) whose language policy themes are determined by the interplay of stakeholders, or agents, operating at micro level. In the context of ELP, relevant agents include supranational organisations, States, legal institutions, universities, and language managers. These broad categories can be further broken down into smaller ones given that agency at university is exercised by students, lecturers, administrators and non-academic support staff. Again, as Spolsky (2009) notes, smaller categories can be further divided into sub-categories, so that ELP could be taught at universities by language professors or lawyer-linguists. Lecturers modify students' language abilities and beliefs based on their own gender, age, social status, training, experience and language proficiency and on those of their students. In the same way, institutions directly connected with the law include the courts, the police and the prisons and, according to Spolsky (2009), "the potential unfairness of the power balance is greatly compounded when some parties lack proficiency in the language of the court" (2009, p. 117). The stakes involved in ELP are, therefore, high indeed.

\section{Micropolitical vs. macropolitical aspects of ELP}

Spolsky's overarching framework also relies on the distinction between the macro and micro levels. The macro level refers to the themes under which language policy operates. These include plurilingualism, multilingualism, 
bilingualism, the European Language Portfolio, social inclusion and social cohesion, employability and CLIL, to name but a few. Such themes evolve to adjust to the priorities of their promoters. For instance, the Council of Europe's promotion of the European Language Portfolio, presented as the companion piece of the CEFRL, has varied over the years. From 2001 to 2011, the Council encouraged the production and promotion of contextualised versions of the European Language Portfolio, then reduced its support for the policy when it was criticised and when portfolios which did not conform to the recommendations of the Council started to proliferate (Barrault-Méthy, 2012). At State level, Languages for Specific Purposes are a top priority for the Czech Republic and considered useful by Bosnia and Herzegovina (European Council of Modern Languages, 2015). In France for Law curricula design, the Conseil National de I'Enseignement Supérieur et de la Recherche (CNESER), an elected academic body, which is also an administrative jurisdiction, recommends a competencebased approach to ELP at Bachelor's level (Conseil National de I'Enseignement Supérieur et de la Recherche, 2012), although the term ELP is not mentioned. This may simply be bowing to academic freedom, which is protected by the constitution, and also not to antagonise language lecturers preferring a more philological approach.

The case of ELP and the CNESER aptly illustrates the interplay between the macro and micro levels. The macro level reflects what happens at micro level, which is that of agents, or stakeholders. The present study will build on Baldauf's definitions of the micro level as concerned by the "processes, relations and dynamic activities" of individuals and groups, with the macro level being that of "fixed objects and structures" (Baldauf, 2006, p. 153).

\section{Positioning theory}

Positioning theory contends that social groups have different rights and duties, and thus use different discursive modes. Harré (2012) defined positioning theory as such: 
...not everyone involved in a social episode has equal access to rights and duties to perform particular kinds of meaningful actions at that moment and with those people. In many interesting cases, the rights and duties determine who can use a certain discourse mode ... A cluster of short-term disputable rights, obligations and duties is called a 'position' (Harré, 2012, p. 193).

Positioning theory has proved particularly effective for analysing political discourse: minority groups have been shown to focus on their rights and majority groups on duties (Moghaddam and Kavulich 2007; Moghaddam et al. 2008). Positioning theory can be applied to the discourse of supranational language policy agents (Barrault-Méthy, 2012). In the present paper, positioning theory's analytical method will be used to unfold the narratives of ELP teacherresearchers, within the same framework, namely Anthropological Structures of the Imaginary theory (Durand, 1969).

\section{ASI theory}

Durand distinguishes two main imaginary "regimes", which are groups of images with their own dynamics. Such regimes allow human experience to be described at individual and societal levels. The first regime, which Durand names "diurnal", markedly differentiates categories which are reunited in the second, the "nocturnal" regime. In the first category, we can find opposite images of hell and heaven. Hell is where the individual is not allowed to exist. It conveys images of animality, of darkness and its substitutes, namely chaos, shock and depression, and of fall-related symbols, for instance original sin and oppression. Heaven is its exact opposite. Images associated with it include upward movement, light and weaponry. Both heaven and hell convey images of distinction, while in the second imaginary regime, reconciliation of opposites prevails. There are two main groups of motives, or symbols, in the second regime, namely the slow descent and the cycle. Images associated with the first group include inversion, repetition, embedding as well as symbols associated to the husk and the heavenly centre. Cyclical symbols comprise initiation and progress. I will show 
how ELP research papers in the corpus relate to the first imaginary regime, in which the motive of clarity belongs.

ASI theory allows images to be described in terms of structures, explanatory principles, dominating reflexes and schemes. Symbols are types of images. Durand defines symbols as endowed with a dynamics of their own: "What is specific to symbols in relation to the centre is that they are centripetal, allegories being centrifugal" (Durand, 1964, p. 11). Two imaginary regimes exist, according to Durand, encompassing human experience as a whole at individual and societal level. Besides symbols, images also consist of structures, explanatory principles, dominating reflexes and schemes, which can be further subdivided into substantives, epithets and verbs. Images appear in a certain order, from opposition for the first imaginary regime, to reconciliation in the second.

\section{Corpus}

The corpus (see table 1 in the annex 1 ) is composed of 68 papers and book chapters written in English or in French dealing with ELP and published across the world between 1989 and 2015. The authors work in universities in 18 countries over four continents. Predictably, the journals with the most articles are English for Specific Purposes (18 papers) followed by ASP (7 papers), a French journal dedicated to "Anglais de spécialité", ESP Across Cultures (4 papers) and GRAAT online ( 3 papers). All other journals appear once or twice in the sample. Overall, there seems to have been a gradual increase in the number of papers published yearly in the field of ELP, peaking to 15 papers in 2010. If we look at the geographical distribution of authors per country of residence, we can observe that ELP is an international, but mostly a European phenomenon, with 42 papers whose authors or co-authors operates in EU universities, particularly in France, which accounts for 32.3 per cent of the papers, followed by the UK, with 8.8 per cent. Outside the EU, 16 per cent of ELP papers originate from Hong Kong and 13.2 per cent from the USA. 
Data in the papers were dispatched in an Excel spreadsheet with four tabs, "motives", "names of publications", "country distribution" and "year". The "motives" tab contained the most data. The taxonomy of motives was established following SAI theory and in relation with the theme of obscurity. Among the analysed papers, two-thirds contained images belonging solely to imaginary regime and one-third was fraught with images belonging to both regimes. The present study builds on the observation of diurnal motives across all papers in the corpus.

\section{Results}

Applying SAI theory to the corpus provides surprisingly homogeneous results. Images related to obscurity in researchers' discourse are organised along several themes, namely animality, depression, the fall and the labyrinth. Regarding the theme of animality, sub-themes include chaos, the swarm and the ogre.

\section{Animality}

Research papers contain numerous references to the chaotic character of ELP. There are many skills to acquire in ELP and at a professional level. Going through its highly specialised vocabulary represents an immense, timeconsuming task. Badea (2012) explains that a part of the teacher-researcher's task consists in vocabulary "mining", a term which denotes some underground, unrecognised, painful work. The chaos of ELP is deeply ingrained in the history of English law. Beveridge (2000) recalls the dispute over the Chancellor's courts and the common law courts which took place at the time of the Tudors and which gave rise to Common law on the one hand, and Equity on the other hand, a completely different body of laws. Such distinction remains today. From 1066 to 1475 , Middle English had no standards or rules and was thus considered a "disordered language". The world of law was, of course, dominated by NormanFrench at that time and most written texts were in Latin or Greek, so much so 
that English was thus not enough to practice law, as noted by an 18th century writer referring to the period 1066-1475. As a result, an "English for lawyers" law was passed in 1731 and modified in 1733 to include customary law and technical words. Such feeling of essential otherness that English law generates is reinforced by the fact that time is an issue in ELP. It takes the ELP researcher a long time to be competent in just one area of law and in just one national context. Beveridge, who is a lawyer-linguist, argues that there are outdated and unnecessary words and phrases in contemporary common law contracts, which makes them difficult to translate and to execute, considering both parties understand the contract with reference to their own legal system. She further notes that sometimes, such contracts do not even make sense. ELP is equated to some sort of wild animal which cannot be dominated, not unlike a devil. According to Beveridge (2000), there are "tricks" in law which consist in manipulating the language for it to be precise and broad at the same time. This is achieved for instance by using a general word and adding examples.

The chaos that is ELP cannot be mastered, due to the very nature of the common law, which is shaped not just by legislators, but also by practitioners. Lawyers themselves being an equal source of law introduce the theme of the swarm. Many court decisions contain detailed discussions as to the meaning of a particular word, phrase or sentence and, as Beveridge (2000) notes, there are volumes about "Words and Phrases Judicially Considered". Common law is also shaped by judges who take part in the law-making process due to the doctrine of stare decisis, which means that judges are bound by previous decisions. This makes ELP an ever-evolving, potentially infinite subject-matter, with the example of a paper exploring the work of just one judge, Lord Mansfield, whose influence on legal thinking was decisive (Charnock 2010). In the same way, legal vocabulary and writing are not static. In the field of litigation, GadbinGeorge (2010) notes that the 1999th Woolf reform prompted procedural changes in English law as well as changes of vocabulary. The ever-evolving character of ELP is reinforced by the numerous and essential intertextual references. Case reports contain numerous references to other legal texts. The ratio decidendi can be understood only in relation to other texts, so that it is of a 
shifting nature. Harris (1997), quoting Twining and Miers (1982), mentions the "buried treasure fallacy" (Twining \& Miers, 1982, cited by Harris 1997), with rules having no fixed verbal form or standard way of posing the issues. The discourse of law is seen to proliferate across legal and paralegal genres, issues and national and international contexts. In her 2011 study Charret-del-Bove (2011), for instance, concentrates on just five terms in one genre within one national context. There are multiple legal genres (Candlin, et al. 2002) and country-specific lexical phenomena created by law professionals, for example, in Canada (Duchet \& Chaulet, 2004), such as variation of the derivational suffix and lexicographic harmonisation of pairs. Local situations are complex and evolving. A new stakeholder has recently appeared in ELP, the legal global firm (Falconbridge \& Muzio, 2009). There is the feeling that the reality of ELP cannot be circumvented. Complexity prevails even at the level of one university with the fear of reaching "unrealistic conclusions" (Deutch, 2004, p. 125) when performing needs analysis with deficiencies, constraints, conflicting demands and requirements. ELP seems to be very much evasive even to native speakers, who may not understand the value of epistemic modality (Cheng \& Cheng, 2014) which, in adjudication, is employed along the same standards in Hong Kong and in Scotland.

The subject of ELP is, understandably, quite humbling, therefore, for researchers, with the recurring image of the ogre prevailing in the corpus. In Badea's opinion (2012), ELP teaching is an enormous task. Bhatia notes the confusion, bewilderment and frustration of Law students when faced with ELP as the student "is not being taught law only - he is being taught a foreign language as well" (1989, p. 223). He further contends that legal English resists common textual analysis, that law cases are dealt with incompletely by ELP teachers, and that research is "scattered". ELP causes a feeling of powerlessness. According to Badea (2012), CLIL, in Law, has failed, while it has proved effective in other contexts. The ogre uses dishonest tactics to maintain a grasp. For Galonnier (2000), metaphors in judgements are part of a manipulative strategy: 
The function of certain phrases and of certain humorous expressions is to establish a complicity which improves acceptance by the profession of an unfavourable judgement or a risky interpretation (...) Using a language which is sometimes colloquial shows the desire to bond with the common man. Yet, we cannot but note that the democratic regard for communication goes hand in hand with an elitist and corporatist feeling (Galonnier, 2000, p. 331).

English judges use metaphors in order to have citizens to accept and thus legitimise their decision.

\section{Depression}

Depression in ELP is conveyed through the sub-themes of blindness, incapacity and the Doppelgänger. The theme of blindness, as regards the researcher, is particularly widespread in ELP research. Newspaper law reports are key texts, but have a limited distribution and are unclear, according to Badger (2003). Researchers' blindness can also be ascribed to the lack of research in the field of English for Academic Legal Purposes (Howe, 1990), and in ELP. In Badger's (2003) opinion, not much is known on the impact of social and cultural elements of the legal discourse, or how research can be used to influence teaching. Focusing on the legal systems of England and Wales, Isani (2010c) explains that they are obscure, and that courtroom attire, with barristers wearing the gown and the wig, reinforces the impression of an inaccessible justice. She notes that a 2007 report indicated that legal professionals wish to retain such attire. Gadbin-George (2010) notes that it has been over a hundred years since the word "legalese" started to be used to describe lawyers' verbose and unintelligible jargon. She explains that according to Bentham (1827), the use of such jargon may well be justified by the bond that seemed to exist between lawyers, who were very conservative. Bentham's view is shared by Bathia (1997a), who notes that the professional legal authority refuses plain English in legislative contexts, and that the undemocratic character of legislative writing can be observed globally. Howe (1990) considers that ELP is more demanding 
for learners than any other subject. Law includes complex structural forms and a particular way of reasoning, distinct from that of other social sciences, and one which has evolved. Howe goes even so far as to suggest that language teachers are incompetent in teaching ELP unless they have some training in law.

The recurrent theme of the incapable ELP teacher is one of the most frequent in the corpus. Bhatia notes that legal concepts are obscure also for native speakers, and that legal English is considered by non-linguist academics as "too important a matter to be left to the English teacher" (1989, p. 223), which is confirmed by Debono (Leconte, 2013). There is a tendency in ELP research to be over-prescriptive towards the ELP teacher. Bruce (2002), for instance, holds that teachers "have to be native" (2002), and further advocates "considerable research in the law of tort and continuing collaboration with the teachers of that course" (2002, p. 321), particularly to teach legal reasoning moves. Freak \& al. (2000) view ELP in an academic context as posing problems even to native speakers. Yet Bruce also admits that the English teacher is "strain[ed]" (2002, p. 340), condemned to be an "amateur" (325), despite having some expert knowledge, while Charnock considers that rhetoric is not sufficiently studied at Law faculties (Charnock, 2002), and that English judges' interpretation is also a major issue (Charnock, 2008). Learners also seem to be prone to the same prescriptive tone, with legal fiction informing their perceptions and modelling their expectations as regards ELP (Isani, 2010b). American legal fiction can thus even create misconceptions among learners about their own legal system, while teachers often rely on their specialist input (Isani, 2011). Comparing legal English writing written by professionals and learners, Hartig \& Xiaofei (2014) found that students tend to overuse the passive voice and nominalisation, thus overplaying the distinctiveness of legalese. It seems that the Plain English movement has not reached academia yet, and that learners equally value obscurity of style.

References to the theme of the Doppelgänger abound in the scientific literature, with ELP being a disquieting version of English as a Foreign Language. The rigidity of ELP has been a cause of concern for centuries, particularly in English law. Each type of action has had its own form of writ, and slight changes 
in form in court declarations and denials could cause the suit to fail (Beveridge 2000). Rigidity is another issue in the language classroom, the constraint of the teaching context rarely favouring oral expression or interaction, and this leading to a further issue, which is the silent learner (Chapon, 2011). Part of the research literature deals with English for Academic Legal Purposes (EALP) but, focusing on it, there is the risk of leaving aside English for Legal Practice, which is yet another branch of ELP (Hafner, 2013). Focusing ELP classes on legal texts, though, is not enough, with Harris noting that a "broadening of EALP outlook is needed: from text to context" (1992, p. 22). There is ever the risk of taking part of ELP for the whole. English law cannot be reduced to Common law as this would omit equity, a separate body of laws. Fiction has its Doppelgänger, i.e., legal fiction, a legal genre which has given rise to a whole body of research and to the concept of Fiction à Substrat Professionnel, or FASP (for instance, De Charentenay, 2001, Isani, 2010a, 2010b), and legal fiction its own Doppelgänger, with forensic fiction. FASP allows teachers to feel on familiar ground as they can apply methods for conducting literary analyses to the study of novels with a legal background. The theme of the double Doppelgänger can also be found in ELP, with legal fiction branching into novels and films with legal content (Csomay \& Petrović, 2012). Courtroom shows are another type of Doppelgänger. The meaning of legal terms, however, may vary from one common law country to another (Beveridge, 2000), and legal terms may not even be identifiable by translators having no legal background (Northcott \& Brown, 2006).

\section{The fall}

Law as a subject is bound to deceive the ELP researcher. Beveridge (2000), a lawyer herself, indicates that the common law is more focused on settling disputes than on establishing the truth. This opens up avenues in analysing justice as a ritual aimed at making society at large to accept decisions taken by an all-powerful court, and goes against any idealistic conception of justice. The theme of the fall abounds in ELP research, associated with that of dizziness. This 
is exemplified by the fascination of research for the ritualistic elements of law such as courtroom attire (see, for instance, Isani, 2010c) and by the fact that ELP research may partake in such ritual, with such recurring themes as legal genre analysis and legal fiction. It is tempting to suggest that genre analysis in a legal setting, after Bhatia (1997a, 1997b), has become a part of the ritual of ELP research. The image of the fall is also manifested through the fact that legal writing is grammatically incorrect (Gadbin-George, 2010), so can be considered as a degraded form of a language. In addition, law cases, dealt only partially in ELP courses (Bhatia 1989) due to their being quite long, are bound to frustrate lecturers.

\section{The labyrinth}

The image of the labyrinth prevails throughout ELP research, which may explain the sense of loss of language expertise when having to deal with legal English (Badea, 2012). The history of legal English is highly complex. Gadbin-George (2010) explains that attempts to reform Norman-French legalese took place in 1362, and that further reforms where initiated by the Mayor of London, the government, the National Consumer Council, Lord Denning, the Law Society, and the Bar Council. As a result of legalese, she contends, justice has become expensive, slow, and not user-friendly, with the language itself being "a major barrier to legal access", citing Lord Woolf (2010, p. 44), and having quite complex rules. It takes time, and money, to get out of the labyrinth of judicial procedures. ELP thus appears as the quintessential language of power, a language with additional dimensions, operating along rules unknown to the general public. There is also nonetheless an element of stability in legalese. Gadbin-George notes that the 1999 Woolf reform, which is part of the Plain English international Movement, may not have changed much, some considering that the reform did "more harm than good" (2010, p. 44). A study of post-1999 documents, which show alliterations and tautologies, suggests that any interest in a change of vocabulary remains debatable. One might even wonder whether the centre of the labyrinth actually exists. Legal translation from one legal 
system of reference makes it especially problematic. Badea (2012) notes that mediation in English between two systems is particularly difficult. When it comes to the standardisation of law across national systems, translation is made even more difficult by the fact that English is also an international language, as explained by Glanert (2005). This remark has important repercussions in ELP teaching, with the reference to national legal systems, international law, and ELF.

\section{Discussion}

ASI theory applied to the research discourse of ELP produces surprising results, as it seems that metaphors are the very fabric of such discourse. Metaphors express a power relation between the researcher and ELP. The positioning of the researcher relates either to the diurnal imaginary regime, with a discourse of intimidation before the not-so-pleasant subject of Law and with the feeling tha ta language must serve Law. The second imaginary regime, which is less polarized and has a discourse focused more on genres and on approaching legal English from an essentialist perspective, nevertheless retains all the trace of the basic schizomorphic structure of ELP research, obscurity being very much of an arch-motive.

One of the limits of the present study clearly rests on metaphor identification as a problematic process. Littlemore $(2001,2003)$ points out that metaphors in university lectures cause problems of understanding among international students, which is quite unexpected for lecturers. Both metaphor identification techniques described by Low et al. (2007) rely on researchers' ability to discriminate between metaphorical and non-metaphorical use of a language. The first technique, the Metaphor Identification Procedure (MIP), rests on isolating lexical items that are used metaphorically (Steen 2004, Pragglejaz Group 2007), leading to quantitative analyses. The second, the Vehicle Identification Procedure, or VPI (Cameron 2003), deals with whole portions of texts and is particularly appropriate for qualitative analysis. The two quantitative and qualitative approaches to metaphor identification are "semi-compatible", as 
Low and al. (2007, p. 430) convene. Durand's approach towards metaphor identification is certainly more holistic and appropriate for qualitative than for quantitative analysis.

But can the whole of ELP research be reduced to two sets of metaphors? According to Richard (2014), metaphors have manipulative aspects as they rely on what two domains, in this case legal English and images of power, have in common, while leaving aside what makes them distinct. Yet, metaphors are useful as they make concepts more accessible (Lakoff \& Johnson, 2003, p. 7, quoted by Richard 2014). The present paper does not pretend to reduce research discourse, but to examine how it is shaped by the institutional context of Law and legal academia.

Secondly, do all papers in our corpus fit into ASI theory categories? On the surface, one paper, a comparative law study from a civilisation perspective, validated by the research community as belonging to the field of Anglophone studies, seems to have escaped such categorisation. The discourse in the paper evades any power relation, possibly as the author is a lecturer in both English and Law. Yet, that paper is equally indicating the unclear boundaries between the research discourses of Applied Linguistics and Law. The present study has left aside transdisciplinary research in forensic linguistics, which is the application of linguistics to the forensic context of law which that will be dealt with in a further study. One might even go so far as to consider that law is a language of its own, with its own special professional culture which that cuts across languages and national differences, and which, in universities, coexists alongside English. The research discourse of ELP can thus be understood in relation to the discourse of Law and of legal academia, as seeking recognition, sometimes espousing their language. This, then, calls upon positioning theory, with the discursive positioning of ELP research and of law recalling that of minority and majority groups noted by Moghaddam and Kavulich (2007) and Moghaddam et al. (2008), with minority groups emphasizing their rights and majority groups their duties. In the present case, under the weight of law, which presents itself as the language of power, ELP seems to be intimidated, with a research discourse sounding more like a justification. 
The ambiguity of the respective positioning of the jurist and of the linguist was previously pinpointed by Glanert (2005) in the context of legal translation. Writing about the standardisation of law across Europe, Glanert holds that linguists are considered as subversive by law experts, as the language of law is both situated in space and time, while ELF is not: "Thus language and national law cannot but disappear when having to deal with the common working language. Here again, the local language is ephemeral in the face of English" (2005, p. 6). In other words, the flexibility of ELF may be perceived as a threat by law experts as globalisation undermines their attempts to stabilize their power within national boundaries through the use of fixed linguistic forms.

\section{Conclusion}

ASI theory allows shedding light on the metadiscourse on power that runs through ELP research. Such discourse revolves around the notion of obscurity, legal English being felt as incomprehensible, manipulative, depressing, and demeaning. By analogy, the discourse of ELP research is often prescriptive, which raises the issue of ownership of language, and of power, which informs ELP research in relation to Law, and which the ELP research community seems to duplicate. Many instances of such discourse on ownership can found in the sample, with stigma attached to the neglectful teacher who would not deal with some issue considered major by a given author. Law-specific ISKDs are inevitable in ELP due to the broadness of ELF, encompassing also law, which is a language in itself. The prevalence of the prescriptive mode in ELP research is equally telling of a widespread tendency to over-manage ELP, compared with other Languages for Specific Purposes (LSPS).

Approaching micropolitics of ELP through ASI theory has important policy implications. It reveals the power relations among academic disciplines and thus, making informed choices regarding course content, not necessarily ignoring such power relations, but at least choosing methods and approaches in a more socially responsible manner. Due to the weight of Law as an academic field, and the needs for ESL teaching in law, there is also a need for teacher 
training in the field of ELP considering the initial bewilderment ELP is likely to generate, as the research has shown. There is also the need for bridging, wherever possible, two fields of study and, outside academia, two mindframes that may prove to be antagonistic, leading to an "aporia" (Glanert, 2005) when operationalising globalisation through uniformisation of laws and practices. At a more theoretical level, ASI theory opens up avenues in approaching macro issues from a micropolitical perspective. More specifically, investigating researcher agency offers a fresh outlook on ESP, at the crossroads between policy, theory and practice.

The results also suggest that Law faculties and universities might be underplaying the role of languages in globalisation. The prevalence of control as a research posture leaves open the question as to whether legal academia and the legal world in general actually control ELP teaching and research. In any case, there is the perception that ELP is a very much constrained subject. It may well be that law experts do not really exercise such control, that it is very much the result of the ELP discourse community projecting some sort of collective psyche. Yet, the possibility exists that legal experts impose a normative view of ELP teaching, which branches out in the research. This is all the more paradoxical considering the role English plays in globalisation, including in the spread of international norms written in English. This would also explain the depth of research in ELF in a legal context. If legal experts have managed to curtail the expansion of ELF for the sake of a disciplinary culture with limited tolerance towards ambiguity, one may wonder whether law makers give languages their just place in society. Lawmakers may, in themselves, resist the expansion of languages other than those in which the law is expressed. Thus, they may simultaneously support multilingualism globally, while undermining it locally.

\section{References}

Badea, E. C. (2012). Teaching Legal English as a Second Language. Anale. Seria Ştiinţe Economice. Timişoara, 18, pp. 832-836. 
Badger, R. (2003). Legal and general: towards a genre analysis of newspaper law reports. English for Specific Purposes, 22 (3), pp. 249-263.

Baldauf, R. 2006. Rearticulating the case for micro language planning in a language ecology context. Current Issues in Language Planning, 7 (23), pp. 147-170. DOI: 10.2167/cilp092.0.

Barrault-Méthy, A. M. 2012. Institutional language policy regarding universities: the contribution of positioning theory. European Journal of Language Policy, 4 (2), pp. 191-216. DOI:10.3828/ejlp.2012.12.

Bentham, J. (1827). Rationale of Judicial Evidence: Specially Applied to English Practice. Vol. 4. London: Hunt \& Clarke.

Beveridge, B. J. (2000). Legal English - How it developed and why it is not appropriate for international commercial contracts. In The Development of Legal Language. Rovaniemi: Finland. Retrieved from http://www.tradulex.com/articles/Beveridge.pdf.

Bhatia, V. K. (1989). Legislative Writing: A case of neglect in EA/OLP Courses. English for Specific Purposes, 8, pp. 223-238.

Bhatia, V. K. (1997a). Genre analysis today. Revue belge de philologie et d'histoire, 75(3), pp. 629-652. DOI: 10.3406/rbph.1997.4186.

Bhatia, V. K. (1997b). The Power and Politics of Genre. Word Englishes, 16 (3), pp. 359-371.

Bruce, N. (2002). Dovetailing language and content: Teaching balanced argument in legal problem answer writing. English for Specific Purposes, 21 (4), pp. 321-345.

Cameron, L. (2003). Metaphor in Educational Discourse. London: Continuum Press.

Canagarajah, S. (1996). From critical research practice to critical research reporting. TESOL Quarterly 30 (2), pp. 321-331. DOI: $10.2307 / 3588146$

Candlin, C. N., Bhatia, V. K., Jensen, C. H., \& Langton, N. (2002). Developing legal writing materials for English second language learners: problems and perspectives. English for Specific Purposes, 21 (4), pp. 299-320. 
Cazade, A. (2000). Recherche/développement en didactique multimédia de I'anglais. Dossier de synthèse pour I'habilitation à diriger des recherches. Université de Poitiers.

Chapon, S. (2011). Vous avez le droit de garder le silence: un scénario pédagogique pour faire parler les étudiants de droit. Cahiers de I'APLIUT, 30 (1), 117 128. DOI: 10.4000/apliut.477.

Charnock, R. (2002). L'argumentation rhétorique et l'enseignement de la langue de spécialité: l'exemple du discours juridique. ASp, pp. 35-36, pp. 121-136. DOI: $10.4000 / a s p .1633$

Charnock, R. (2008). Raisonnement linguistique chez les juges anglais: le cas de I'interprétation des testaments. Lidil, Revue de linguistique et de didactique des langues, 38, pp. 109-124.

Charnock, R. (2010). Raisonnement juridique et intuition de la justice chez Lord Mansfield, CJ. GRAAT online, 7, pp. 23-46. Retrieved from: http://www.graat.fr/j-charnock.pdf.

Cheng, W., \& Cheng, L. (2014). Epistemic modality in court judgments: A corpus-driven comparison of civil cases in Hong Kong and Scotland. English for Specific Purposes, 33, pp. 15-26. DOI: 10.1016/j.esp.2013.07.006.

Conseil National de l'Enseignement Supérieur et de la Recherche (2012). Référentiel de compétences en licence. Retrieved from http://cache.media.enseignementsuprecherche.gouv.fr/file/Plan_licence/61/4/referentiel_227614.pdf.

Csomay, E., \& Petrović, M. (2012). « Yes, your honor! »: A corpus-based study of technical vocabulary in discipline-related movies and TV shows. System, 40 (2), pp. 305-315. DOI: 10.1016/j.system.2012.05.004.

De Charentenay, R. (2001). La fiction à substrat professionnel (FASP): un(e) média(tion) pas comme les autres. ASp, pp. 31-33. DOI: 10.4000/asp.1962.

Deutch, Y. (2003). Needs analysis for academic legal English courses in Israel: a model of setting priorities. Journal of English for Academic Purposes, 2, pp. 125-146. DOI: 10.1016/S1475-1585(03)00013-4. 
Dressen-Hammouda, D. (2014). Measuring the voice of disciplinarity in scientific writing: A longitudinal exploration of experienced writers in geology. English for Specific Purposes, 34, pp. 14-25.

DOI:16/j.esp.2013.10.001.

Duchet, J.-L., \& Chaulet, O. (2004). Étude de I'affixation dérivationnelle par traitement automatique du lexique juridique canadien. ASp, pp. 43-44, pp. 81-98. DOI: 10.4000/asp.1070.

Durand, G. (1964). L'Imagination symbolique. Paris: Presses Universitaires de France.

Durand, G. (1969). Les Structures anthropologiques de l'imaginaire. Paris: Dunod.

European Council of Modern Languages (2015). Detailed Overview of National Priorities. Retrieved from:

http://govboard.ecml.at/LinkClick.aspx?fileticket=W\%2b78BKZAqF8\% 3d\&tabid $=3556$ \&language $=$ en-GB.

Faulconbridge, J. R., \& Muzio, D. (2009). Legal education, globalization and cultures of professional practice. Georgetown Journal of Legal Ethics, 21, pp. 1335-1359.

Feak, C. B., Reinhart, S. M., \& Sinsheimer, A. (2000). A preliminary analysis of law review notes. English for Specific Purposes, 19, pp. 197-220.

Gadbin-George, G. (2010). The Woolf reform of civil procedure: a possible end to legalese? LSP Journal-Language for special purposes, professional communication, knowledge management and cognition, 1 (2). Retrieved from http://cjas.dk/index.php/lspcog/article/view/3076.

Galonnier, B. (2000). La métaphore dans les jugements anglais: nature et fonction. ASp, 27, pp. 325-335. DOI: 10.4000/asp.2260.

Glanert, S. (2005). Le juriste subverti: réflexions traductologiques à I'heure de I'uniformisation des droits en Europe. Meta, 50 (5). DOI: 10.7202/019842ar.

Hafner, C. A. (2013). The discursive construction of professional expertise: Appeals to authority in barrister's opinions. English for Specific Purposes, 32 (3), pp. 131-143. DOI: 10.1016/j.esp.2013.01.003. 
Harré, R. (2012). Positioning theory: moral dimensions of social-cultural psychology. In J. Valsiner (Ed.) The Oxford Handbook of Culture and Psychology, pp. 191-206. New York: Oxford University.

Harris, S. (1997). Procedural Vocabulary in Law Case Reports. English for Specific Purposes, 16 (4), pp. 289-308.

Hartig, A. J., \& Lu, X. (2014). Plain English and legal writing: Comparing expert and novice writers. English for Specific Purposes, 33, pp. 87-96. DOI: 10.1016/j.esp.2013.09.001.

Howe, P. M. (1990). The Problem of the Problem Question in English for Academic Legal Purposes. English for Specific Purposes, 9, pp. 215236.

Isani, S. (2010a). Bench \& Bar in Popular Legal Fiction. A Comparative Approach to Fictional Representations and Public Perceptions. GRAAT online, 7, pp. 182-200. Retrieved from http://www.graat.fr/j-isani.pdf.

Isani, S. (2010b). Quand la science enquête: imaginaires \& représentations de la FASP criminalistique. ILCEA, 12. Retrieved from http://ilcea.revues.org/index583.html.

Isani, S. (2010c). Semiotic dialectics of legal courtroom attire and the crosscultural erosion of professional identity. ESP Across Cultures, 7, pp. 89-103.

Lakoff, G. \& Johnson, M. (2003). Metaphors We Live By, London: The University of Chicago Press.

Leconte, F. (2013). Langue et droit: approche sociolinguistique, historique et épistémologique. Glottopol, 23, pp. 190-193.

Littlemore, J. 2001. The use of metaphor in university lectures and the problems that it causes for overseas students. Teaching in Higher Education 6 (3), pp. 333-51.

Littlemore, J. 2003. The effect of cultural background on metaphor interpretation. Metaphor and Symbol, 18 (4), pp. 273-88.

Low, G., Littlemore, J., \& Koester, A. (2007). Metaphor Use in Three UK University Lectures. Applied Linguistics, 29 (3), pp. 428-455. DOI:10.1093/applin/amn008. 
Moghaddam, F. M., Harré, R., \& Lee, N. (2008). Global conflict resolution through positioning analysis. New York: Springer.

Moghaddam, F. M., and Kavulich, K. A. (2007). Nuclear Positioning. In J. Valsiner and A. Rosa (Eds), The Cambridge Handbook of Sociocultural Psychology, pp. 576-590. New York: Cambridge University Press.

Northcott, J., \& Brown, G. (2006). Legal translator training: Partnership between teachers of English for legal purposes and legal specialists. English for Specific Purposes, 25 (3), pp. 358-375.

DOI: $10.1016 /$ j.esp.2005.08.003.

Norton, B. \& Early, M. (2011). Researcher Identity, Narrative Inquiry, and Language Teaching research. TESOL Quarterly 45 (3), pp. 415-439. DOI: $10.5054 /$ tq.2011.261161.

Pragglejaz Group. (2007). A practical and flexible method for identifying metaphorically-used words in discourse. Metaphor and Symbol, 22 (1), pp. $1-40$.

Richard, I. (2014). Metaphors in English for Law: Let Us Keep Them! Lexis, 103.

Steen, G. (2004). What counts as a metaphorically used word? The Pragglejaz experience. in S. Coulson and B. Lewandowska (Eds) The LiteralNonliteral Distinction, pp. 299-322. Berlin: Peter Lang.

Spolsky, B. (2009). Language Management. Cambridge: Cambridge University Press.

Twining, W., \& Miers, D. (1982). How to do things with rules. London: Weidenfield and Nicholson.

Van der Yeught, M. (2012). L'anglais de la bourse et de la finance. Paris: Ophrys.

Wu, H., \& Badger, R. G. (2009). In a strange and uncharted land: ESP teachers' strategies for dealing with unpredicted problems in subject knowledge during class. English for Specific Purposes, 28 (1), pp. 19-32. DOI: 10.1016/j.esp.2008.09.003. 
Annex 1

Table 1

\section{Corpus of ELP papers}

\begin{tabular}{|c|c|c|c|c|}
\hline Author & Year & Title & Publication & $\begin{array}{l}\text { Author's } \\
\text { country of } \\
\text { residence }\end{array}$ \\
\hline Badea, E. C. & 2012 & $\begin{array}{l}\text { Teaching legal English } \\
\text { as a second language }\end{array}$ & $\begin{array}{l}\text { Anale. Seria } \\
\text { Ştiinţe } \\
\text { Economice. } \\
\text { Timişoara }\end{array}$ & Romania \\
\hline Badger, R. & 2003 & $\begin{array}{l}\text { Legal and general: } \\
\text { towards a genre analysis } \\
\text { of newspaper law } \\
\text { reports }\end{array}$ & $\begin{array}{l}\text { English for } \\
\text { Specific } \\
\text { Purposes }\end{array}$ & UK \\
\hline Beveridge, B. & 2000 & $\begin{array}{l}\text { Legal English - How it } \\
\text { developed and why it is } \\
\text { not appropriate for } \\
\text { international commercial } \\
\text { contracts }\end{array}$ & $\begin{array}{l}\text { The } \\
\text { Development } \\
\text { of Legal } \\
\text { Language. } \\
\text { Symposium on } \\
\text { Legal } \\
\text { Linguistics, } \\
\text { Rovaniemi, } \\
\text { Finland }\end{array}$ & Canada \\
\hline $\begin{array}{l}\text { Bhatia, V. K., } \\
\text { Candlin, C. N. }\end{array}$ & 2004 & $\begin{array}{l}\text { Analysing arbitration } \\
\text { laws across legal } \\
\text { systems }\end{array}$ & $\begin{array}{l}\text { Hermes, } \\
\text { Journal of } \\
\text { Linguistics }\end{array}$ & $\begin{array}{l}\text { Hong Kong } \\
\text { and } \\
\text { Australia }\end{array}$ \\
\hline Bhatia, V. K. & 1989 & $\begin{array}{l}\text { Legislative Writing : A } \\
\text { case of neglect in } \\
\text { EA/OLP Courses }\end{array}$ & $\begin{array}{l}\text { English for } \\
\text { Specific } \\
\text { Purposes }\end{array}$ & Hong Kong \\
\hline Bhatia, V. K. & 1997 & Genre analysis today & $\begin{array}{l}\text { Revue belge } \\
\text { de philologie } \\
\text { et d'histoire }\end{array}$ & Hong Kong \\
\hline Bhatia, V. K. & 1997 & $\begin{array}{l}\text { The Power and Politics of } \\
\text { Genre }\end{array}$ & $\begin{array}{l}\text { World } \\
\text { Englishes }\end{array}$ & Hong Kong \\
\hline Bloor, M. & 1998 & $\begin{array}{l}\text { English for Specific } \\
\text { Purposes: The } \\
\text { Preservation of the } \\
\text { Species (some notes on } \\
\text { a recently evolved } \\
\text { species and on the } \\
\text { contribution of John } \\
\text { Swales to its } \\
\text { preservation and } \\
\text { protection) }\end{array}$ & $\begin{array}{l}\text { English for } \\
\text { Specific } \\
\text { Purposes }\end{array}$ & UK \\
\hline Botezat, $\mathrm{O}$. & 2010 & $\begin{array}{l}\text { Discourse Markers } \\
\text { Sentence Openers in } \\
\text { Legal English }\end{array}$ & $\begin{array}{l}\text { EIRP } \\
\text { Proceedings }\end{array}$ & Turkey \\
\hline Bowles, $\mathrm{H}$. & 1995 & $\begin{array}{l}\text { Why are newspaper law } \\
\text { reports so hard to } \\
\text { understand? }\end{array}$ & $\begin{array}{l}\text { English for } \\
\text { Specific } \\
\text { Purposes }\end{array}$ & Italy \\
\hline
\end{tabular}


OBSCURITY IN THE MICROPOLITICS OF ENGLISH FOR LEGAL PURPOSES: TOWARDS AN ANTHROPOLOGICAL FRAMEWORK

\begin{tabular}{|c|c|c|c|c|}
\hline Author & Year & Title & Publication & $\begin{array}{l}\text { Author's } \\
\text { country of } \\
\text { residence }\end{array}$ \\
\hline Bruce, N. & 2002 & $\begin{array}{l}\text { Dovetailing language } \\
\text { and content: Teaching } \\
\text { balanced argument in } \\
\text { legal problem answer } \\
\text { writing }\end{array}$ & $\begin{array}{l}\text { English for } \\
\text { Specific } \\
\text { Purposes }\end{array}$ & Hong Kong \\
\hline Campos, M. A. & 2010 & $\begin{array}{l}\text { Going beyond the } \\
\text { obvious in English for } \\
\text { Legal Purposes: a few } \\
\text { remarks on International } \\
\text { Legal English as a } \\
\text { Lingua Franca in Europe }\end{array}$ & $\begin{array}{l}\text { Professional } \\
\text { English in the } \\
\text { European } \\
\text { context: the } \\
\text { EHEA } \\
\text { challenge }\end{array}$ & Spain \\
\hline $\begin{array}{l}\text { Candlin, C. N., } \\
\text { Bhatia, V. K., } \\
\text { Jensen, C. H., \& } \\
\text { Langton, N. }\end{array}$ & 2002 & $\begin{array}{l}\text { Developing legal writing } \\
\text { materials for English } \\
\text { second language } \\
\text { learners: Problems and } \\
\text { Perspectives }\end{array}$ & $\begin{array}{l}\text { English for } \\
\text { Specific } \\
\text { Purposes }\end{array}$ & Hong Kong \\
\hline Chapon, S. & 2011 & $\begin{array}{l}\text { Vous avez le droit de } \\
\text { garder le silence: un } \\
\text { scénario pédagogique } \\
\text { pour faire parler les } \\
\text { étudiants de droit } \\
\end{array}$ & $\begin{array}{l}\text { English for } \\
\text { Specific } \\
\text { Purposes }\end{array}$ & France \\
\hline Charnock, R. & 2002 & $\begin{array}{l}\text { L'argumentation } \\
\text { rhétorique et } \\
\text { l'enseignement de la } \\
\text { langue de spécialité : } \\
\text { l'exemple du discours } \\
\text { juridique }\end{array}$ & ASP & France \\
\hline Charnock, R. & 2008 & $\begin{array}{l}\text { Raisonnement } \\
\text { linguistique chez les } \\
\text { juges anglais : le cas de } \\
\text { l'interprétation des } \\
\text { testaments }\end{array}$ & LIDIL & France \\
\hline Charnock, R. & 2010 & $\begin{array}{l}\text { Raisonnement juridique } \\
\text { et intuition de la justice } \\
\text { chez Lord Mansfield, C.J. }\end{array}$ & GRAAT online & France \\
\hline $\begin{array}{l}\text { Charret-Del-Bove, } \\
\text { M. }\end{array}$ & 2011 & $\begin{array}{l}\text { Quelle place occupe } \\
\text { l'anglais juridique dans } \\
\text { les offres de stages } \\
\text { proposés par les } \\
\text { cabinets d'avocats en } \\
\text { Angleterre et au pays de } \\
\text { Galles? }\end{array}$ & ASP & France \\
\hline $\begin{array}{l}\text { Cheng, W., \& } \\
\text { Cheng, L. }\end{array}$ & 2014 & $\begin{array}{l}\text { Epistemic modality in } \\
\text { court judgements: a } \\
\text { corpus-driven } \\
\text { comparison of civil cases } \\
\text { in Hong Kong and } \\
\text { Scotland }\end{array}$ & $\begin{array}{l}\text { English for } \\
\text { Specific } \\
\text { Purposes }\end{array}$ & $\begin{array}{l}\text { Hong Kong } \\
\text { and China }\end{array}$ \\
\hline
\end{tabular}




\begin{tabular}{|c|c|c|c|c|}
\hline Author & Year & Title & Publication & $\begin{array}{l}\text { Author's } \\
\text { country of } \\
\text { residence }\end{array}$ \\
\hline $\begin{array}{l}\text { Candlin, C. N., } \\
\text { Bhatia, V. K., \& } \\
\text { Jensen, C. H. }\end{array}$ & 2002 & $\begin{array}{l}\text { Must the Worlds Collide? } \\
\text { Professional and } \\
\text { Academic Discourses in } \\
\text { the Study and Practice } \\
\text { of Law }\end{array}$ & $\begin{array}{l}\text { Peter Lang } \\
\text { book }\end{array}$ & Hong Kong \\
\hline Coulthard, M. & 2011 & $\begin{array}{l}\text { Critical linguistic analysis } \\
\text { in a legal context }\end{array}$ & $\begin{array}{l}\text { Pragmatics } \\
\text { and Society }\end{array}$ & UK \\
\hline $\begin{array}{l}\text { Csomay, E., \& } \\
\text { Petrović, M. }\end{array}$ & 2012 & $\begin{array}{l}\text { "Yes, your honor!": A } \\
\text { corpus-based study of } \\
\text { technical vocabulary in } \\
\text { discipline-related movies } \\
\text { and TV shows }\end{array}$ & System & USA \\
\hline $\begin{array}{l}\text { De Charentenay, } \\
\text { R. }\end{array}$ & 2001 & $\begin{array}{l}\text { La fiction à substrat } \\
\text { professionnel (FASP) : } \\
\text { un(e) média(tion) pas } \\
\text { comme les autres }\end{array}$ & ASP & France \\
\hline Deckert, Sharon K. & 2010 & $\begin{array}{l}\text { Co-animation of and } \\
\text { Resistance to the } \\
\text { Construction of Witness, } \\
\text { Victim and Perpetrator } \\
\text { Identities in Forensic } \\
\text { Interviews with Children }\end{array}$ & $\begin{array}{l}\text { Critical Inquiry } \\
\text { in Language } \\
\text { Studies }\end{array}$ & USA \\
\hline Deutch, Y. & 2003 & $\begin{array}{l}\text { Needs analysis for } \\
\text { academic legal English } \\
\text { courses in Israel: a } \\
\text { model of setting } \\
\text { priorities }\end{array}$ & $\begin{array}{l}\text { Journal of } \\
\text { English for } \\
\text { Academic } \\
\text { Purposes }\end{array}$ & Israel \\
\hline $\begin{array}{l}\text { Duchet, J. L., \& } \\
\text { Chaulet, O. }\end{array}$ & 2004 & $\begin{array}{l}\text { Étude de l'affixation } \\
\text { dérivationnelle par } \\
\text { traitement automatique } \\
\text { du lexique juridique } \\
\text { canadien }\end{array}$ & ASP & France \\
\hline $\begin{array}{l}\text { Fan, M., \& } \\
\text { Xunfeng, X. }\end{array}$ & 2002 & $\begin{array}{l}\text { An evaluation of an } \\
\text { online bilingual corpus } \\
\text { for the self-learning of } \\
\text { legal English }\end{array}$ & System & Hong Kong \\
\hline $\begin{array}{l}\text { Faulconbridge, J. } \\
\text { R., \& Muzio, D. }\end{array}$ & 2009 & $\begin{array}{l}\text { Globalization, and } \\
\text { Cultures of Professional } \\
\text { Practice }\end{array}$ & $\begin{array}{l}\text { Georgetown } \\
\text { Journal of } \\
\text { Legal Ethics }\end{array}$ & USA \\
\hline $\begin{array}{l}\text { Freak, C. B., } \\
\text { Reinhart, S. M., \& } \\
\text { Sinsheimer, A. }\end{array}$ & 2002 & $\begin{array}{l}\text { A preliminary analysis of } \\
\text { law review notes }\end{array}$ & $\begin{array}{l}\text { English for } \\
\text { Specific } \\
\text { Purposes }\end{array}$ & USA \\
\hline Gadbin-George, G. & 2010 & $\begin{array}{l}\text { The Woolf reform of civil } \\
\text { procedure: a possible } \\
\text { end to legalese? }\end{array}$ & LSP Journal & France \\
\hline Galonnier, B. & 2000 & $\begin{array}{l}\text { La Métaphore dans les } \\
\text { jugements anglais: } \\
\text { nature et fonction }\end{array}$ & ASP & France \\
\hline
\end{tabular}


OBSCURITY IN THE MICROPOLITICS OF ENGLISH FOR LEGAL PURPOSES: TOWARDS AN ANTHROPOLOGICAL FRAMEWORK

\begin{tabular}{|c|c|c|c|c|}
\hline Author & Year & Title & Publication & $\begin{array}{l}\text { Author's } \\
\text { country of } \\
\text { residence }\end{array}$ \\
\hline Gibson, E. & 2010 & $\begin{array}{l}\text { L'évolution de la } \\
\text { responsabilité des juges } \\
\text { en France et en } \\
\text { Angleterre }\end{array}$ & GRAAT online & France \\
\hline Glanert, S. & 2006 & $\begin{array}{l}\text { La langue en héritage: } \\
\text { réflexions sur } \\
\text { l'uniformisation des } \\
\text { droits en Europe }\end{array}$ & $\begin{array}{l}\text { Revue } \\
\text { internationale } \\
\text { de droit } \\
\text { comparé }\end{array}$ & France \\
\hline Glanert, S. & 2005 & $\begin{array}{l}\text { Le juriste } \\
\text { subverti : réflexions } \\
\text { traductologiques à } \\
\text { l'heure de } \\
\text { l'uniformisation des } \\
\text { droits en Europe }\end{array}$ & Méta & France \\
\hline Leconte, F. & 2014 & $\begin{array}{l}\text { Langue et droit - } \\
\text { Approche } \\
\text { sociolinguistique, } \\
\text { historique et } \\
\text { épistémologique }\end{array}$ & Glottopol & France \\
\hline Goddard, C. & 2009 & $\begin{array}{l}\text { Where legal cultures } \\
\text { meet: Translating } \\
\text { confrontation into } \\
\text { coexistence }\end{array}$ & $\begin{array}{l}\text { Investigationes } \\
\text { Linguisticae }\end{array}$ & Latvia \\
\hline Goddard, C. & 2010 & $\begin{array}{l}\text { Legal Linguistics as an } \\
\text { Academic and } \\
\text { Professional Discipline: } \\
\text { Identifying Clients, } \\
\text { Customers, } \\
\text { Stakeholders }\end{array}$ & $\begin{array}{l}\text { Online } \\
\text { proceedings of } \\
\text { the XVII } \\
\text { European LSP } \\
\text { Symposium } \\
2009 \\
\end{array}$ & Latvia \\
\hline Goddard, C. & 2010 & $\begin{array}{l}\text { Didactic aspects of legal } \\
\text { English: dynamics of } \\
\text { course preparation }\end{array}$ & $\begin{array}{l}\text { ESP Across } \\
\text { Cultures }\end{array}$ & Finland \\
\hline Greenstein, R. & 2011 & $\begin{array}{l}\text { Le sens des mots dans } \\
\text { un contexte juridique }\end{array}$ & $\begin{array}{l}\text { Le fil de Paris } \\
\text { (non-scientific } \\
\text { publication) }\end{array}$ & France \\
\hline $\begin{array}{l}\text { Hafner, C. A., \& } \\
\text { Candlin, C. N. }\end{array}$ & 2007 & $\begin{array}{l}\text { Corpus tools as an } \\
\text { affordance to learning in } \\
\text { professional legal } \\
\text { education }\end{array}$ & $\begin{array}{l}\text { Journal of } \\
\text { English for } \\
\text { Academic } \\
\text { Purposes }\end{array}$ & $\begin{array}{l}\text { Hong Kong } \\
\text { and } \\
\text { Australia }\end{array}$ \\
\hline Hafner, C. A. & 2013 & $\begin{array}{l}\text { The Discursive } \\
\text { construction of } \\
\text { professional expertise: } \\
\text { Appeals to authority in } \\
\text { barrister's opinions }\end{array}$ & $\begin{array}{l}\text { English for } \\
\text { Specific } \\
\text { Purposes }\end{array}$ & Hong Kong \\
\hline Harris, S. & 1992 & $\begin{array}{l}\text { Reaching out in Legal } \\
\text { Education: Will EALP be } \\
\text { there? }\end{array}$ & $\begin{array}{l}\text { English for } \\
\text { Specific } \\
\text { Purposes }\end{array}$ & UK \\
\hline
\end{tabular}


Anne-Marie BARRAULT-MÉTHY

\begin{tabular}{|c|c|c|c|c|}
\hline Author & Year & Title & Publication & $\begin{array}{l}\text { Author's } \\
\text { country of } \\
\text { residence }\end{array}$ \\
\hline Harris, S. & 1997 & $\begin{array}{l}\text { Procedural vocabulary in } \\
\text { law case reports }\end{array}$ & $\begin{array}{l}\text { English for } \\
\text { Specific } \\
\text { Purposes }\end{array}$ & Mexico \\
\hline $\begin{array}{l}\text { Hartig, A. J., \& } \\
\text { Xiaofei, L. }\end{array}$ & 2014 & $\begin{array}{l}\text { Plain English and legal } \\
\text { Writing: Comparing } \\
\text { expert and novice } \\
\text { writers }\end{array}$ & $\begin{array}{l}\text { English for } \\
\text { Specific } \\
\text { Purposes }\end{array}$ & USA \\
\hline Howe, P. M. & 1990 & $\begin{array}{l}\text { The Problem of the } \\
\text { Problem Question in } \\
\text { English for Academic } \\
\text { Legal Purpose }\end{array}$ & $\begin{array}{l}\text { English for } \\
\text { Specific } \\
\text { Purposes }\end{array}$ & UK \\
\hline Isani, $\mathrm{S}$. & 2005 & $\begin{array}{l}\text { From idealisation to } \\
\text { demonisation and in- } \\
\text { between: } \\
\text { representations of } \\
\text { American lawyers in } \\
\text { legal FASP }\end{array}$ & ASP & France \\
\hline Isani, $\mathrm{S}$. & 2010 & $\begin{array}{l}\text { Bench \& Bar in Popular } \\
\text { Legal Fiction: A } \\
\text { Comparative Approach } \\
\text { to Fictional } \\
\text { Representations and } \\
\text { Public Perceptions }\end{array}$ & GRAAT online & France \\
\hline Isani, $\mathrm{S}$. & 2010 & $\begin{array}{l}\text { Quand la science } \\
\text { enquête : imaginaires \& } \\
\text { représentations de la } \\
\text { FASP criminalistique }\end{array}$ & ILCEA & France \\
\hline Isani, $\mathrm{S}$. & 2010 & $\begin{array}{l}\text { Semiotic dialectics of } \\
\text { legal courtroom attire } \\
\text { and the cross-cultural } \\
\text { erosion of professional } \\
\text { identity }\end{array}$ & $\begin{array}{l}\text { ESP Across } \\
\text { Cultures }\end{array}$ & France \\
\hline Isani, S. & 2011 & $\begin{array}{l}\text { English for Legal } \\
\text { Purposes and domain- } \\
\text { specific cultural } \\
\text { awareness }\end{array}$ & Book & France \\
\hline Robertson, C. & 2010 & $\begin{array}{l}\text { Legislative drafting in } \\
\text { English for non-native } \\
\text { speakers: some dos and } \\
\text { don'ts with reference to } \\
\text { EU legislation }\end{array}$ & $\begin{array}{l}\text { ESP Across } \\
\text { Cultures }\end{array}$ & $\begin{array}{l}\text { Not } \\
\text { specified - } \\
\text { EU }\end{array}$ \\
\hline Janulevičienè, V. & 2011 & $\begin{array}{l}\text { Clarity versus accuracy } \\
\text { and objectivity in written } \\
\text { legal English }\end{array}$ & $\begin{array}{l}\text { Santalka: } \\
\text { Filologija, } \\
\text { Edukologija }\end{array}$ & Lithuania \\
\hline Lung, J. & 2008 & $\begin{array}{l}\text { Discursive hierarchical } \\
\text { patterning in Law and } \\
\text { Management Cases }\end{array}$ & $\begin{array}{l}\text { English for } \\
\text { Specific } \\
\text { Purposes }\end{array}$ & China \\
\hline
\end{tabular}


OBSCURITY IN THE MICROPOLITICS OF ENGLISH FOR LEGAL PURPOSES: TOWARDS AN ANTHROPOLOGICAL FRAMEWORK

\begin{tabular}{|c|c|c|c|c|}
\hline Author & Year & Title & Publication & $\begin{array}{l}\text { Author's } \\
\text { country of } \\
\text { residence }\end{array}$ \\
\hline $\begin{array}{l}\text { Northcott, J, \& } \\
\text { Brown, G. }\end{array}$ & 2006 & $\begin{array}{l}\text { Legal translator training: } \\
\text { Partnership between } \\
\text { teachers of English for } \\
\text { legal purposes and legal } \\
\text { specialists }\end{array}$ & $\begin{array}{l}\text { English for } \\
\text { Specific } \\
\text { Purposes }\end{array}$ & UK \\
\hline Orts Llopis, M. A. & 2009 & $\begin{array}{l}\text { Legal genres in English } \\
\text { and Spanish: Some } \\
\text { attempts of analysis }\end{array}$ & Ibérica & Spain \\
\hline Péchou, A. & 2005 & $\begin{array}{l}\text { Aider à comprendre une } \\
\text { conférence. Le cas du } \\
\text { droit des contrats pour } \\
\text { étayer la motivation }\end{array}$ & $\begin{array}{l}\text { Recherche et } \\
\text { Pratiques } \\
\text { Pédagogiques } \\
\text { en Langues de } \\
\text { Spécialité }\end{array}$ & France \\
\hline Richard, I. & 2006 & $\begin{array}{l}\text { L'évolution de l'emploi } \\
\text { de shall, de must et du } \\
\text { présent simple dans le } \\
\text { discours juridique } \\
\text { normatif dans le cadre } \\
\text { du Plain Language } \\
\text { Movement }\end{array}$ & ASP & France \\
\hline Richard, I. & 2014 & $\begin{array}{l}\text { Metaphors in English } \\
\text { law: let us keep them! }\end{array}$ & ASP & France \\
\hline Robertson, C. B. & 2010 & $\begin{array}{l}\text { A Collaborative Model of } \\
\text { Offshore Legal } \\
\text { Outsourcing }\end{array}$ & $\begin{array}{l}\text { Working } \\
\text { paper, Social } \\
\text { Science } \\
\text { Research } \\
\text { Network } \\
\text { Electronic } \\
\text { Paper } \\
\text { Collection } \\
\end{array}$ & France \\
\hline Silver, C. & 2006 & $\begin{array}{l}\text { Internationalizing US } \\
\text { legal education: a } \\
\text { Report on the Education } \\
\text { of Transnational Lawyers }\end{array}$ & $\begin{array}{l}\text { Working } \\
\text { paper, Indiana } \\
\text { University } \\
\text { Paper } \\
\text { Repository } \\
\end{array}$ & USA \\
\hline Song, B. & 2006 & $\begin{array}{l}\text { Content-based ESL } \\
\text { instruction: Long-term } \\
\text { effects and outcomes }\end{array}$ & $\begin{array}{l}\text { English for } \\
\text { Specific } \\
\text { Purposes }\end{array}$ & USA \\
\hline Tessuto, G. & 2011 & $\begin{array}{l}\text { Legal Problem Question } \\
\text { Answer Genre across } \\
\text { jurisdictions and cultures }\end{array}$ & $\begin{array}{l}\text { English for } \\
\text { Specific } \\
\text { Purposes }\end{array}$ & Italy \\
\hline Tessuto, G. & 2015 & $\begin{array}{l}\text { Generic structure and } \\
\text { rhetorical moves in } \\
\text { English-language } \\
\text { empirical law research } \\
\text { articles: Sites of } \\
\text { interdisciplinary and } \\
\text { interdiscursive cross- } \\
\text { over }\end{array}$ & $\begin{array}{l}\text { English for } \\
\text { Specific } \\
\text { Purposes }\end{array}$ & Italy \\
\hline
\end{tabular}


Anne-Marie BARRAULT-MÉTHY

\begin{tabular}{|l|l|l|l|l|}
\hline Author & Year & Title & Publication & $\begin{array}{l}\text { Author's } \\
\text { country of } \\
\text { residence }\end{array}$ \\
\hline Trinch, S. & 2010 & $\begin{array}{l}\text { Disappearing discourse: } \\
\text { performative texts and } \\
\text { identity in legal contexts }\end{array}$ & $\begin{array}{l}\text { Critical Inquiry } \\
\text { in Language } \\
\text { Studies }\end{array}$ & USA \\
\hline Trosborg, A. & 1995 & $\begin{array}{l}\text { Statutes and contracts: } \\
\text { An analysis of legal } \\
\text { speech acts in the } \\
\text { English language of the } \\
\text { law }\end{array}$ & $\begin{array}{l}\text { Journal of } \\
\text { Pragmatics }\end{array}$ & Denmark \\
\hline Vass, H. & 2004 & $\begin{array}{l}\text { Socio-cognitive aspects } \\
\text { of hedging in two legal } \\
\text { discourse genres }\end{array}$ & Ibérica & Spain \\
\hline Vystrčilova, R. & 2000 & Legal English & Philosophica & $\begin{array}{l}\text { The Czech } \\
\text { Republic }\end{array}$ \\
\hline
\end{tabular}

\section{Anne-Marie Barrault-Méthy}

Bordeaux universitetas, Prancūzija; ambmethy@ambmethy.net

\section{"MIGLOTUMAS" TEISINĖS ANGLU KALBOS MIKROPOLITIKOJE IR ANTROPOLOGINĖJE SISTEMOJE}

Santrauka. Per pastaruosius 30 metu teisinès anglu kalbos tyrimai suintensyvejo, taip pat padidejo ir daugiašalis teisinio mokymo populiarumas. Šio darbo tikslas - apžvelgti teisinès anglu kalbos (ELP) santyki su teisiniu studiju globalizacija, atsižvelgiant i tai, kad teisinè kalbos taksonomija/sistematika daugiausiai išlieka nacionalinè. Ši analizè apima Antropologiniu vaizdiniu struktūru teorijos (ASI) taikymą kalbos politikos kontekste, apžvelgiama, kaip tyrejjai ir istatymu ekspertai nustato teisinès anglu kalbos padèti vieni kitu atžvilgiu. Šiame darbe demesys skiriamas "pozicijos" sąvokai. Analizuojami 68 tekstyno vaizdiniai leidžia daryti prielaida, kad "miglotumo" tema yra svarbiausia ELP diskurse. Su galia siejami ivaizdžiai skirstomi i keturias kategorijas: gyvūniškuma, iduba, rudeni ir labirinta. ASI teorijos indèlis i ELP mikropolitikos tyrinejjima yra dvejopas. ASI teorija paaiškina galios metadiskursa, kuris vyrauja ELP tyrime, ir padeda suprasti veikiančiojo padèties nustatymą. ASI teorija taikoma ELP tiriamajame darbe padeda išsklaidyti abejones, iškylančias hibridineje anglu lingua franca kalboje, su kuriomis susiduria teisinès anglu kalbos tyrèjai bei teisès ekspertai.

Pagrindinès sąvokos: kalbos valdymo teorija, specialios paskirties kalbos, teisinè anglu kalba, Atropologiniu vaizdiniu struktūru teorija (Anthropological Structures of the Imaginary theory), padeties nustatymo teorija (positioning theory), mikropolitinis lygmuo. 